\title{
The correlation between osteoporosis occurrences in both Schizophrenia and Parkinson's disease
}

\author{
Fatemeh Radaei ${ }^{1}$, Asma Darvishi ${ }^{2}$ and Shahriar Gharibzadeh ${ }^{1}$ * \\ ${ }^{1}$ Neural and Cognitive Sciences Laboratory, Biomedical Engineering Faculty, Amirkabir University of Technology, Tehran, Iran \\ ${ }^{2}$ Tehran University of Medical Sciences, Tehran, Iran \\ *Correspondence: gharibzadeh@aut.ac.ir \\ Edited by: \\ Jordi Blanch, Hospital Clínic de Barcelona, Spain \\ Reviewed by: \\ Varun Kesherwani, University of Nebraska Medical Center, USA
}

Keywords: Parkinson's disease, schizophrenia, osteoporosis, AMPK, energy metabolism

Osteoporosis disease is a metabolic disorder in which bone mineral density (BMD) is lower than the normal threshold. Based on literature, it is known that schizophrenic patients due to consuming anti-psychotic drugs and Parkinson's disease patients due to vitamin $\mathrm{D}$ deficiency and decrease in mobility are at the high risk of osteoporosis (1-4).

On the other hand, it is observed that adenosine $5^{\prime}$-monophosphate (AMP)activated protein kinase (AMPK) activity, which is regulating cellular energy homeostasis, is reduced in schizophrenia diseases (5). In addition, it is known that there is mitochondrial dysfunction in Parkinson's disease that can be treated by AMPK, which is identified as a mitochondrial biogenesis (6-8). Recently, some findings show that AMPK plays an important role in bone metabolism. Besides, some in vitro studies revealing that AMPK modulators regulate bone cell function (9-13). Also, some studies show that deficiency of AMPK $\alpha$ and $\beta$ subunits in mice causes bone loss in vivo (14).

Based on the above mentioned points, it can be referred that AMPK deficiency in Parkinson's disease and schizophrenia may lead to osteoporosis. This can be used as a goal in treatment of osteoporosis in those disorders. In another word, nowadays there are some drugs available for both diseases but they have some side effect, which may lead to osteoporosis; by considering the fact that AMPK deficiency may cause osteoporosis, new drugs can be provided with AMPK supplement to reduce the osteoporosis symptoms. Surely, experimental trials are needed to validate our hypothesis.

\section{REFERENCES}

1. van den Bos F, Speelman AD, Samson M, Munneke M, Bloem BR, Verhaar HJ. Parkinson's disease and osteoporosis. Age Ageing (2013) 42(2):156-62. doi:10.1093/ageing/afs161

2. Miyamoto S, Duncan GE, Marx CE, Lieberman JA. Treatments for schizophrenia: a critical review of pharmacology and mechanisms of action of antipsychotic drugs. Mol Psychiatry (2005) 10(1):79-104. doi:10.1038/sj.mp.4001556

3. Holt RI, Peveler RC. Antipsychotics and hyperprolactinaemia: mechanism, consequence and management. Clin Endocrinol (2011) 74(2):141-7. doi: 10.1111/j.1365-2265.2010.03814.x

4. Goodnick PJ, Santana O, Rodriguez L. Antipsychotics: impact on prolactin levels. Expert Opin Pharmacother (2002) 3(10):1381-91. doi:10.1517/ 14656566.3.10.1381

5. Tardito D, Tura GB, Bocchio L, Bignotti S, Pioli R, Racagni G, et al. Abnormal levels of cAMP dependent protein kinase regulatory subunits in platelets from schizophrenic patients. Neuropsychopharmacology (2000) 23(2):216-9. doi:10.1016/S0893133X(99)00161-X

6. Zhu J, Chu CT. Mitochondrial dysfunction in Parkinson's disease. J Alzheimers Dis (2010) 20(1):325-34. doi:10.3233/JAD-2010-100363

7. Richard MR, Gerald IS. The role of AMP-activated protein kinase in mitochondrial biogenesis. J Physiol (2006) 574(Pt 1):33-9. doi:10.1113/jphysiol. 2006.109512

8. Bayliss JA, Andrews ZB. Ghrelin is neuroprotective in Parkinson's disease: molecular mechanisms of metabolic neuroprotection. Ther Adv Endocrinol Metab (2013) 4(1):25-36. doi:10.1177/ 2042018813479645

9. Molinuevo MS, Schurman L, McCarthy AD, Cortizo AM, Tolosa MJ, Gangoiti MV, et al. Effect of metformin on bone marrow progenitor cell differentiation: in vivo and in vitro studies. $J$ Bone Miner Res (2010) 25(2):211-21. doi:10.1359/jbmr. 090732

10. Quinn JM, Tam S, Sims NA, Saleh H, McGregor NE, Poulton IJ, et al. Germline deletion of
AMP-activated protein kinase $\beta$ subunits reduces bone mass without altering osteoclast differentiation or function. FASEB J (2010) 24(1):275-85. doi:10.1096/fj.09-137158

11. Shah M, Kola B, Bataveljic A, Arnett TR, Viollet B, Saxon L, et al. AMP-activated protein kinase (AMPK) activation regulates in vitro bone formation and bone mass. Bone (2010) 47(2):309-19. doi:10.1016/j.bone.2010.04.596

12. Jang WG, Kim EJ, Bae I-H, Lee K-N, Kim YD, Kim $\mathrm{D}-\mathrm{K}$, et al. Metformin induces osteoblast differentiation via orphan nuclear receptor SHP-mediated transactivation of Runx2. Bone (2011) 48(4):88593. doi:10.1016/j.bone.2010.12.003

13. Mai Q, Zhang Z, Xu S, Lu M, Zhou R, Zhao $\mathrm{L}$, et al. Metformin stimulates osteoprotegerin and reduces RANKL expression in osteoblasts and ovariectomized rats. J Cell Biochem (2011) 112(10):2902-9. doi:10.1002/jcb.23206

14. Jeyabalan J, Shah M, Viollet B, Chenu C. AMPactivated protein kinase pathway and bone metabolism. J Endocrinol (2012) 212(3):277-90. doi:10. 1530/JOE-11-0306

Conflict of Interest Statement: The authors declare that the research was conducted in the absence of any commercial or financial relationships that could be construed as a potential conflict of interest.

Received: 13 February 2014; accepted: 16 May 2014; published online: 02 June 2014.

Citation: Radaei F, Darvishi A and Gharibzadeh S (2014) The correlation between osteoporosis occurrences in both Schizophrenia and Parkinson's disease. Front. Neurol. 5:83. doi: 10.3389/fneur.2014.00083

This article was submitted to Neurodegeneration, a section of the journal Frontiers in Neurology. Copyright (C) 2014 Radaei, Darvishi and Gharibzadeh. This is an open-access article distributed under the terms of the Creative Commons Attribution License (CC BY). The use, distribution or reproduction in other forums is permitted, provided the original author(s) or licensor are credited and that the original publication in this journal is cited, in accordance with accepted academic practice. No use, distribution or reproduction is permitted which does not comply with these terms. 